\title{
Elevated vascular resistance after labetalol during resection of a pheochromocytoma (Brief report)
} [Élévation de la résistance vasculaire générale après l'administration de labétalol pendant la résection d'un phéochromocytome]

Peter C.H. Chung MD, Allen H. Li MD, Chih Chung Lin MD, Ming Wen Yang MD

Purpose: To report a case of pheochromocytoma exhibiting an increase in systemic vascular resistance index (SVRI) and decreased cardiac index $(\mathrm{Cl})$ after use of labetalol.

Clinical features: A 36-yr-old male underwent adrenectomy for pheochromocytoma. Midazolam $5 \mathrm{mg}$, fentanyl $100 \mu \mathrm{g}$ and labetalol $20 \mathrm{mg}$ were administrated intravenously for premedication upon arrival in the operating theatre. After induction of anesthesia with fentanyl, thiopental and atracurium, $30 \mathrm{mg}$ iv labetalol was administered. The blood pressure gradually rose to $178 / 101$ $\mathrm{mmHg}$ with mildly increased SVRI ( $\left.1958 \mathrm{dn}-\mathrm{sec}^{-1} \cdot \mathrm{m}^{2} \cdot \mathrm{cm}^{5}\right)$ and stable $\mathrm{Cl}\left(3.8 \mathrm{~L} \cdot \mathrm{min}^{-1} \cdot \mathrm{m}^{2}\right)$. The blood pressure reached $247 / / 50$ $\mathrm{mmHg}$ after intubation with an increase in SVRI (3458 dn$\left.\mathrm{sec}^{-1} \cdot \mathrm{m}^{2} \cdot \mathrm{cm}^{5}\right)$ and a decrease in $\mathrm{Cl}\left(3.6 \mathrm{~L} \cdot \mathrm{min}^{-1} \cdot \mathrm{m}^{2}\right)$. The SVRI increased further to $4986 \mathrm{dn}-\mathrm{sec}^{-1} \cdot \mathrm{m}^{2} \cdot \mathrm{cm}^{5}$ and $\mathrm{Cl}$ declined to 2.4 $\mathrm{L} \cdot \mathrm{min}^{-1} \cdot \mathrm{m}^{2}$ after the administration of additional labetalol $20 \mathrm{mg}$. Sodium nitroprusside was administered and the blood pressure declined immediately to $108 / 72 \mathrm{mmHg}$, with a decreased SVRI (2526 dn- $\left.\mathrm{sec}^{-1} \cdot \mathrm{m}^{2} \cdot \mathrm{cm}^{5}\right)$ and stable $\mathrm{Cl}\left(2.3 \mathrm{~L} \cdot \mathrm{min}^{-1} \cdot \mathrm{m}^{2}\right)$.

Conclusions: The elevated SVRI with low $\mathrm{Cl}$ was considered to result from increased -adrenergic activity secondary to ß- adrenergic blockade with labetalol. Clinicians should be aware of the possibility of a hypertensive crisis after iv labetalol. We suggest that labetalol should be replaced promptly with -adrenergic blockers or other vasodilators when such a condition arises.

Objectif : Rapporter un cas de phéochromocytome présentant une augmentation de l'index de résistance vasculaire générale (IRVG) et une baisse de l'index cardiaque (IC) à la suite de l'usage de labétalol.

Éléments cliniques: Un homme de 36 ans a subi une surrénalectomie pour un phéochromocytome. On lui a administré par voie intraveineuse $5 \mathrm{mg}$ de midazolam, 100 ig de fentanyl et $20 \mathrm{mg}$ de labétalol comme prémédication à l'arrivée au bloc opératoire. Après l'induction anesthésique avec du fentanyl, du thiopental et de l'atracurium, $30 \mathrm{mg}$ de labétalol iv ont été donnés. La tension artérielle est montée graduellement à 178/101 mmHg et l'IRVG a augmenté légèrement à $1958 \mathrm{dn}-\mathrm{sec}^{-1} \cdot \mathrm{m}^{2} \cdot \mathrm{cm}^{5}$ tandis que l'lC est resté stable à 3,8 L· $\mathrm{min}^{-1} \cdot \mathrm{m}^{2}$. La tension a atteint $247 / 150 \mathrm{mmHg}$ après l'intubation, I'IRVG s'est élevé à $3458 \mathrm{dn}-\mathrm{sec}^{-1} \cdot \mathrm{m}^{2} \cdot \mathrm{cm}^{5}$ et l'IC a baissé à 3,6 $\mathrm{L} \cdot \mathrm{min}^{-1} \cdot \mathrm{m} 2$. L'IRVG a augmenté encore à $4986 \mathrm{dn}-\mathrm{sec}^{-1} \cdot \mathrm{m}^{2} \cdot \mathrm{cm}^{5}$ et I'IC a baissé à 2,4 L.min ${ }^{-1} \cdot \mathrm{m}^{2}$ après l'administration de $20 \mathrm{mg}$ supplémentaires de labétalol. Du nitroprussiate de sodium a été administré et la tension artérielle a immédiatement baissé à 108/72 mmHg, I'IRVG a baissé à $2526 \mathrm{dn}-\mathrm{sec}^{-1} \cdot \mathrm{m}^{2} \cdot \mathrm{cm}^{5}$ et l'IC est demeuré stable à 2,3 L.min $\mathrm{min}^{-1} \cdot \mathrm{m}^{2}$.

Conclusion: L'IRVG élevé, accompagné d'un IC faible, a été jugé comme le résultat d'une augmentation de l'activité -adrénergique secondaire au blocage B-adrénergique provoqué par le labétalol. II faut penser à la possibilité d'une crise hypertensive avec l'usage iv de labétalol. Dans ce cas, le labétalol devrait être remplacé rapidement par des inhibiteurs -adrénergiques ou d'autres vasodilatateurs.

\section{Clinical features}

A 36-yr-old male with a history of hypertension for six years and occasional syncope for four months was admitted. His 24-hr urine VMA was $12.9 \mathrm{ng} \cdot \mathrm{mL}^{-1}$ (normal range: $\left.2-7 \mathrm{ng} \cdot \mathrm{mL}^{-1}\right)$. A right adrenal tumour of $3.5 \mathrm{~cm}$ in diameter was visualized with computer tomographic scanning, and $\mathrm{I}^{131}$-metaiodobenzyl guanidine scintigraphy showed a positive shadow. Under the impression of pheochromocytoma, adrenectomy was scheduled. Preoperative physical examination revealed no apparent abnormality. Blood sugar was normal, but electrocardiography (ECG) showed sinus tachycardia with ventricular premature contractions. Labetalol $(200 \mathrm{mg}) \mathrm{l} \#$ bid and nifedipine $(10 \mathrm{mg}) \mathrm{l} \#$ qid were prescribed and the cardiac rhythm became regular. His 48 -hr in-hospital blood

From the Department of Anesthesiology, Chang Gung Memorial Hospital, Tao-Yuan, Taiwan.

Address correspondence to: Dr. Peter C.H. Chung, Department of Anesthesiology, Chang Gung Memorial Hospital, 5 Fu-Hsing Street,

Kwei-Shan, Tao-Yuan, 333, Taiwan. Phone: +886-3-3281200, ext. 2389; Fax: +886-2-28737816; E-mail: steve226@ms23.hinet.net Accepted for publication September 5, 2001.

Revision accepted for November 5, 2001.

CAN J ANESTH 2002/49:2/pp 148-150 
pressure remained between $120 / 80$ and $130 / 90$ $\mathrm{mmHg}$. On the morning of surgery, oral medications were administered as usual. Upon arrival in the operation theatre, blood pressure was $156 / 92 \mathrm{mmHg}$ and heart rate 70 beats. $\mathrm{min}^{-1}$. Midazolam $5 \mathrm{mg}$, fentanyl $100 \mu \mathrm{g}$ and labetalol $20 \mathrm{mg}$ were administered intravenously for premedication. Blood pressure was $150 / 95 \mathrm{mmHg}$. Monitors included ECG, pulse oximetry, continuous arterial blood pressure via a radial artery catheter, and a pulmonary artery catheter inserted via the right internal jugular vein. After insertion of the pulmonary artery catheter under local anesthesia with $1 \%$ lidocaine, systolic blood pressure was between 160 and $170 \mathrm{mmHg}$. The cardiac output $(\mathrm{CO})$ was monitored with a continuous CO monitor (Vigilance monitor, model VGS, Edwards Critical Care Division, Baxter Healthcare Corperation ). Anesthesia was then induced with fentanyl $200 \mu \mathrm{g}, 2.5 \%$ sodium thiopental $250 \mathrm{mg}$, and atracurium $40 \mathrm{mg}$ intravenously. After loss of eyelash reflex, isoflurane $3.5 \%$ in oxygen $3 \mathrm{~L} \cdot \mathrm{min}^{-1}$ was administered via a face mask, with an expired concentration of isoflurane between 1.2 and $1.5 \%$. Ventilation was easy with an oxygen saturation of $100 \%$. Blood pressure was $147 / 85 \mathrm{mmHg}$. Labetalol was administered in $10 \mathrm{mg}$ iv boluses, up to a total dosage of $30 \mathrm{mg}$. Blood pressure gradually increased to $178 / 101 \mathrm{mmHg}$. Mildly increased SVRI (1958 dn$\left.\mathrm{sec}^{-1} \cdot \mathrm{m}^{2} \cdot \mathrm{cm}^{5}\right)$ and stable CI $\left(3.8 \mathrm{~L} \cdot \mathrm{min}^{-1} \cdot \mathrm{m}^{2}\right)$ were recorded. After intubation, blood pressure increased to $247 / 150 \mathrm{mmHg}$ with a further increase in SVRI $(3458$ $\left.\mathrm{dn}-\mathrm{sec}^{-1} \cdot \mathrm{m}^{2} \cdot \mathrm{cm}^{5}\right)$ and a mild decrease in CI $(3.6$ $\left.\mathrm{L} \cdot \mathrm{min}^{-1} \cdot \mathrm{m}^{2}\right)$, as shown in the Figure. After an additional dose of labetalol $20 \mathrm{mg} i v$, the blood pressure declined to $219 / 133 \mathrm{mmHg}$ with a CI of $2.4 \mathrm{~L} \cdot \mathrm{min}^{-1} \cdot \mathrm{m}^{2}$. However, the SVRI remained elevated (4986 dn$\left.\mathrm{sec}^{-1} \cdot \mathrm{m}^{2} \cdot \mathrm{cm}^{5}\right)$. Sodium nitroprusside was administered and the blood pressure declined immediately to $108 / 72$ $\mathrm{mmHg}$, with a decreased SVRI $\left(2526 \mathrm{dn}-\mathrm{sec}^{-1} \cdot \mathrm{m}^{2} \cdot \mathrm{cm}^{5}\right)$ and stable CI $\left(2.3 \mathrm{~L} \cdot \mathrm{min}^{-1} \cdot \mathrm{m}^{2}\right)$.

During tumour manipulation and resection, sodium nitroprusside was administered to control the elevated blood pressure $(216 / 137 \mathrm{mmHg})$ and SVRI $\left(5029 \mathrm{dn}-\mathrm{sec}^{-1} \cdot \mathrm{m}^{2} \cdot \mathrm{cm}^{5}\right)$. The blood pressure drop after tumour resection (blood pressure $77 / 52 \mathrm{mmHg}$ and SVRI $\left.1635 \mathrm{dn}-\mathrm{sec}^{-1} \cdot \mathrm{m}^{2} \cdot \mathrm{cm}^{5}\right)$ was treated with dopamine. In the postoperating room, blood pressure was elevated mildly due to wound pain, and subsided after $25 \mathrm{mg}$ of $i v$ meperidine.

\section{Discussion}

During the induction of anesthesia, the elevated SVRI with a low CI was considered to result from increased -adrenergic activity secondary to $B$-adrenergic blockade with labetalol.

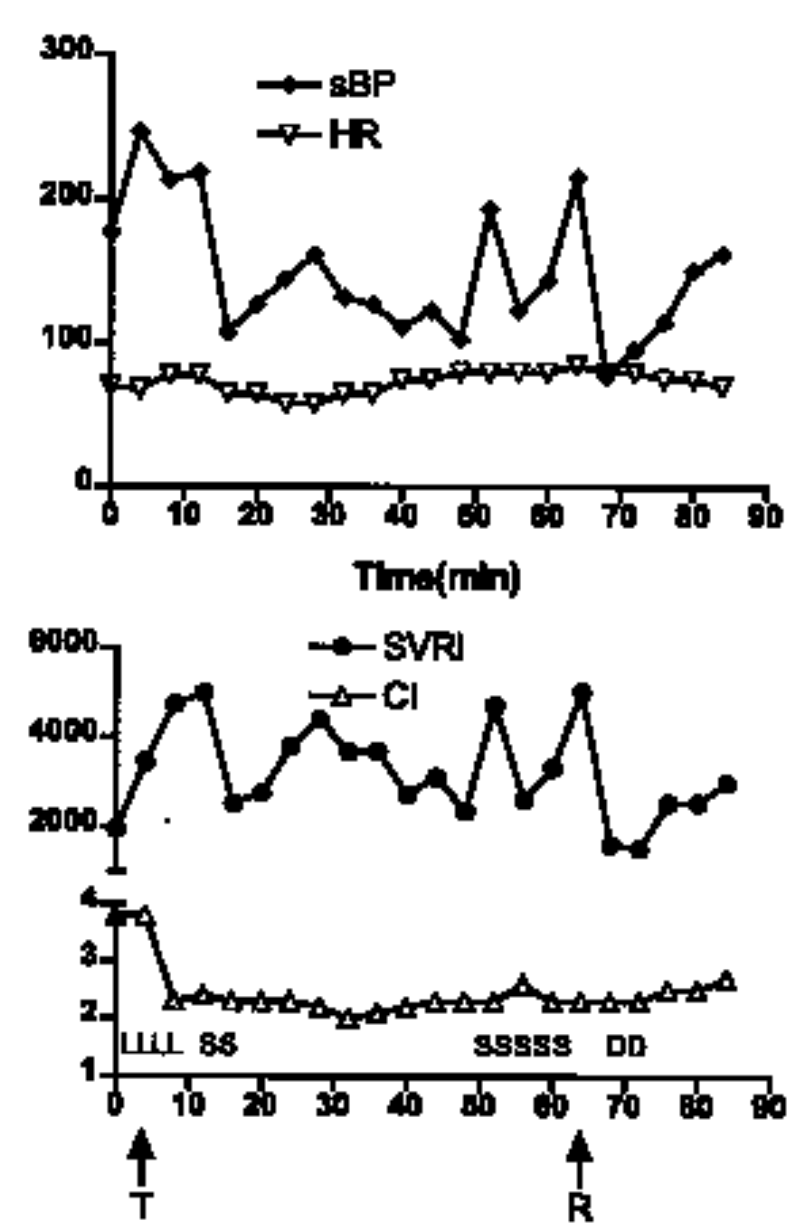

FIGURE Changes in systolic blood pressure (sBP, $\mathrm{mmHg}$ ), heart rate $\left(\mathrm{HR}\right.$, beats. $\left.\mathrm{min}^{-1}\right)$, systemic vascular resistance index (SVRI, dn- $\mathrm{sec}^{-1} \cdot \mathrm{m}^{2} \cdot \mathrm{cm}^{5}$ ) and cardiac index $\left(\mathrm{CI}, \mathrm{L} \cdot \mathrm{min}^{-1} \cdot \mathrm{m}^{2}\right)$ during intubation and resection of pheochromocytoma, and the timing of administration of labetalol, sodium nitroprusside and dopamine.

Generally, during the treatment of hypertension, if $B$-adrenergic receptors are blocked first, norepinephrine and epinephrine will produce unopposed -adrenergic stimulation. $\beta_{2}$-mediated vasodilation will not be able to offset ${ }_{1}$ vasoconstriction, and peripheral vascular resistance will increase. ${ }^{1}$ Theoretically, without adequate -adrenergic blockade, $B$-adrenergic blockade may result in high peripheral vascular resistance and hypertension. Therefore, weak -adrenergic blockade and strong $B$-adrenergic blockade are not an ideal combination for an anti-hypertensive agent. However, labetalol is such an agent and has been used effectively for years as an anti-hypertensive agent without 
reports of high vascular resistance, ${ }^{2-5}$ even in patients with norepinephrine-secreting pheochromocytoma. ${ }^{6}$ But, as the use of continuous $\mathrm{CO}$ monitoring becomes more widespread, hemodynamic changes following the use of labetalol can be demonstrated more clearly. It can provide more accurate and reliable information on $\mathrm{CO}$ than the traditional devices, ${ }^{7}$ especially in a hemodynamic emergency such as during pheochromocytoma resection. With a coiled heater at the tip of the pulmonary artery catheter, $\mathrm{CO}$ can be estimated every ten seconds, and the average value of the last few $\mathrm{CO}$ measurements can be displayed, as can $30 \mathrm{~min}$ to $24 \mathrm{hr}$ trends of CO.

In this case, the blood pressure increased while $\mathrm{CO}$ remained stable after administration of labetalol before intubation, and the blood pressure continued to increase despite a decrease in $\mathrm{CO}$ after increasing doses of labetalol after intubation. In our experience, the combination of fentanyl $\left(5 \mu \mathrm{g} \cdot \mathrm{kg}^{-1}\right)$, thiopental ( 5 $\left.\mathrm{mg} \cdot \mathrm{kg}^{-1}\right)$, labetalol $\left(0.5-1 \mathrm{mg} \cdot \mathrm{kg}^{-1}\right)$, and isoflurane with an expired concentration between 1.2 and $1.5 \%$ provides adequate anesthesia for intubation. So, we concluded that the increase in blood pressure was related mainly to the administration of labetalol.

The aim of this report is to remind clinicians of the possibility of SVRI elevation and hypertensive crisis after iv labetalol. We suggest that labetalol should be replaced promptly with -adrenergic blockers or other vasodilators when such a condition arises, in order to prevent the possible cardiac and pulmonary complications induced by further $B$-blockade.

\section{References}

1 Morgan GE, Mikbail MS. Adrenergic agonists and antagonists. In: Morgan GE, Mikhail MS (Eds.).

Clinical Anesthesiology, 2nd ed. London: Prentice Hall International (UK) Limited, 1996: 183-5.

2 Farmer JB, Kennedy I, Levy GP, Marshall RJ. Pharmacology of AH 5158; a drug which blocks both and B-adrenoceptors. Br J Pharmacol 1972; 45: 660-75.

3 Bailey RR. Labetalol in the treatment of a patient with phaeochromocytoma: a case report. Br J Clin Pharmacol 1979; 8: 141S-2S.

4 Kanfman $L$. Use of labetalol during hypotensive anaesthesia and in the management of phaeochromocytoma. Br J Clin Pharmacol 1979; 8: 229S-32S.

5 Chung PCH, Sum DCW, Wu RSC. High dose intravenous labetalol for the resection of metastatic pheochromocytoma. Acta Anaesthesiol Sin 1996; 34: 235-8.

6 Chung PCH, Sum DCW. Preliminary experience of using fixed dose of intravenous labetalol in surgical resection of pheochromocytoma. Acta Anaesthesiol Sin 1993; 31: 211-6.
7 Boldt J, Menges T, Wollbruck M, Hammermann $H$, Hempelmann G. Is continuous cardiac output measurement using thermodilution reliable in the critically ill patient? Crit Care Med 1994; 22: 1913-8. 